\title{
ASSOCIATION BETWEEN PARENTAL INCOME AT PREGNANCY, PARENTING TIME, AND NUTRITIONAL STATUS IN CHILDREN AGED 7-12 MONTHS IN KUPANG, EAST NUSA TENGGARA
}

\author{
Agung Dirgantara Namangboling
}

Masters Program in Nutrition, Sebelas Maret University

\begin{abstract}
Background: Nutritional status in children can be affected by various factors such as exclusive breastfeeding, food intake, parental income, parenting time, and maternal working status. This study aimed to investigate association between parental income at pregnancy, parenting time, nutritional status in children aged 7-12 months in Kupang, East Nusa Tenggara.
\end{abstract}

Subjects and Method: This was an analytic abservational study with case control desgin. The study was conducted in Kelapa Lima sub district, Kupang, East Nusa Tenggara, from April to June, 2017. A sample of 116 children age 712 months was selected using fixed disease sampling. The dependent variable was nutrition status (weight for height). The independent variables were parenting time and parental income at pregnancy. The data were collected using weight scale, microtoise, and questionnaire. The data was analyzed using multiple logistic regression.

Results: High parental income at pregnancy $(\mathrm{OR}=2.37 ; 95 \% \mathrm{CI}=1.08$ to $5.19 ; \mathrm{p}=0.031)$ and parenting time $(\mathrm{OR}=3.91 ; 95 \% \mathrm{CI}=1.62$ to $9.44 ; \mathrm{p}=$ 0.002) were associated with better nutritional status (weight for height) in children aged 7-12 months.

Conclusion: Parental income at pregnancy and parenting time are associated with nutritional status in children aged 7-12 months.

Keywords: nutritional status, weight for height, children aged 7-12 months, parental income, parenting time, pregnancy

Correspondence: Agung Dirgantara Namangboling. Masters Program in Nutrition, Sebelas Maret University, Jl. Ir. Sutami 36 A, Surakarta 57126, Central Java. Email: akomang46@gmail.com. Mobile: +6281331983923. 